\title{
Radiation Risk Assessment of Soil in Idomi, Cross River State, Nigeria
}

\author{
N.O. Chiaghanam ${ }^{1 *}$, C. C. Nzotta $^{2}$, L. B. Enweani ${ }^{2}$ \\ ${ }^{1}$ Department of Radiography and Radiological Science, University of Calabar \\ Calabar, Nigeria \\ ${ }^{2}$ Department of Radiography and Radiological Science, Nnamdi Azikiwe University \\ Nnewi Campus, Nigeria \\ ${ }^{*}$ Correspondence author's email: nochiaghanamm [AT] gmail.com
}

\begin{abstract}
In this thesis work, the radiation risk from soil samples in Idomi community located at Yakurr Local Government Area of Cross River State, Nigeria was studied. This was because of an earlier study that revealed the presence of high radioactivity in the area. This study aim to determine the background radiation levels, estimate their effective dose, the mean activity concentrations of the radionuclide and the radiological implications of the radioactivity levels in Idomi. Thirty (30) soil samples were collected and analyzed. The baseline average annual outdoor effective dose, mean activity concentration, gamma absorbed dose and radiological hazard index were studied. Results from this study indicate that three (3) radionuclide namely ${ }^{40} \mathrm{~K},{ }^{238} \mathrm{U}$ and ${ }^{232} \mathrm{Th}$ were present in the soil samples analyzed. The mean activity concentrations of ${ }^{40} \mathrm{~K},{ }^{238} \mathrm{U}$ and ${ }^{232} \mathrm{Th}$ in the soil samples were $506.13 \pm 9.30,41.14 \pm 3.59$ and $84.52 \pm 20.88$ $B q \mathrm{~kg}^{-1}$ respectively. The calculated mean external and internal hazard index was 0.62 and 0.71 respectively. The calculated mean gamma index was 0.86 . The Raeq in the soil samples was $227.34 \mathrm{Bqkg}^{-1}$. The calculated absorbed gamma dose from the sample was $110.31 \mathrm{GGy}^{-1}$ and a mean annual outdoor effective dose of $1.35 \mathrm{mSvy} \mathrm{y}^{-1}$. Compared with global average values of 10-200nGy ${ }^{-1}, 2.4 \mathrm{mSvy}^{-1}$ and $\mathrm{Ra}_{e q}$ of $370 \mathrm{BqKg^{-1 }}$ they can be said to be within the normal range. From this study, the chances of occurrence of health effects from exposure to natural terrestrial gamma radiation in Idomi can be said to be low. This may be possible if the baseline levels obtained from this study can be kept constant by keeping the environment free of radioactive pollution.
\end{abstract}

Keywords--- Radiation, Risk, Assessment, Soil, Activity

\section{INTRODUCTION}

Human being has been exposed to radiation, $85 \%$ of which is natural and $15 \%$ artificial (NRPB, 1994). Natural background radiation originates from the terrestrial environment and varies tremendously worldwide and within countries as well (Hendry et. al, 2009). About $90 \%$ of radiation from the ground are derived from the natural radioactivity originating from the top 15 to $23 \mathrm{~cm}$ of the ground area with an outcrop of rock density $2.7 \mathrm{glc} . \mathrm{c}$ or 30 to $45 \mathrm{~cm}$ area with dry overburden with density of $1.5 \mathrm{gl}$.c (Uwa, 1993). The remaining $10 \%$ or less comes from nuclear debris which occurs as a surface layer foliage containment.

The terrestrial component of the natural background radiation is dependent on the compositions of soil, rocks and some building materials which typically contain natural radionuclides Uranium-238 $\left({ }^{238} \mathrm{u}\right)$, Thorium$232\left({ }^{232} \mathrm{Th}\right)$ and Potassium- $40\left({ }^{40} \mathrm{k}\right)$. In the last decade plus, a lot of studies on soil radioactivity has been going on worldwide.

Aeoradiometric studies using a scintillometer of Ugep area in Cross River State, Nigeria shows exposure rates between 1.3 to $4.5 \mu \mathrm{R} / \mathrm{h}$. (Uwah,1993). Idomi community is located within this area and recorded the highest exposure value. The aeroradiometric study shows that the area recorded the highest exposure rate (Ekwueme, 1990). This area is characterized by the upper Proterozoic garnetiferous mica schist intruded by a N-S foliated Pan- Africa porphyritic biotite granite body of older granite series (Ekwueme, 1995).

The presence of primordial radionuclides in granite is a potential source of terrestrial radioactivity in the environment. Hence, this study aims to establish the background level, activity, radiation hazards and distribution of these primordial radionuclides in the soil of Idomi. 


\section{STUDY AREA}

Idomi community lies within Ugep area in Yakurr Local Government Area of Cross River State, Nigeria. It lies within the meridians $8^{0} 15^{\prime} \mathrm{E}$ and $5^{0} 40^{\prime} \mathrm{N}$ and $5^{0} 50^{\prime} \mathrm{N}$. Its lithological formation indicates that it is made up of siltstone, sandstone, shale, Marl, Schist and Gneiss. The area covers $15 \mathrm{~km}^{2}$.It is an agrarian community surrounded by other communities with adjoining water bodies and hills.

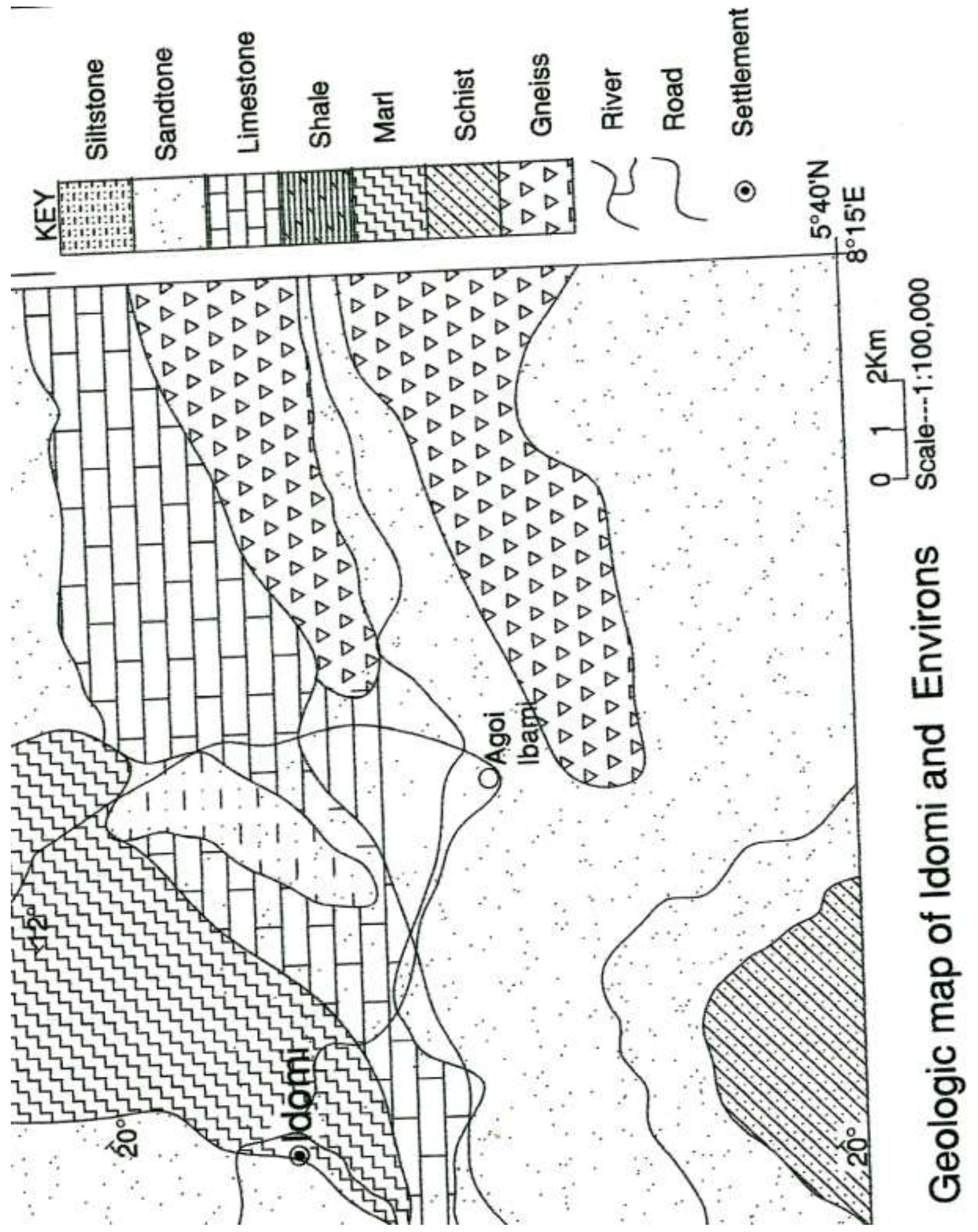

Fig. 1: Map of Idomi and environs with its Lithological formations 


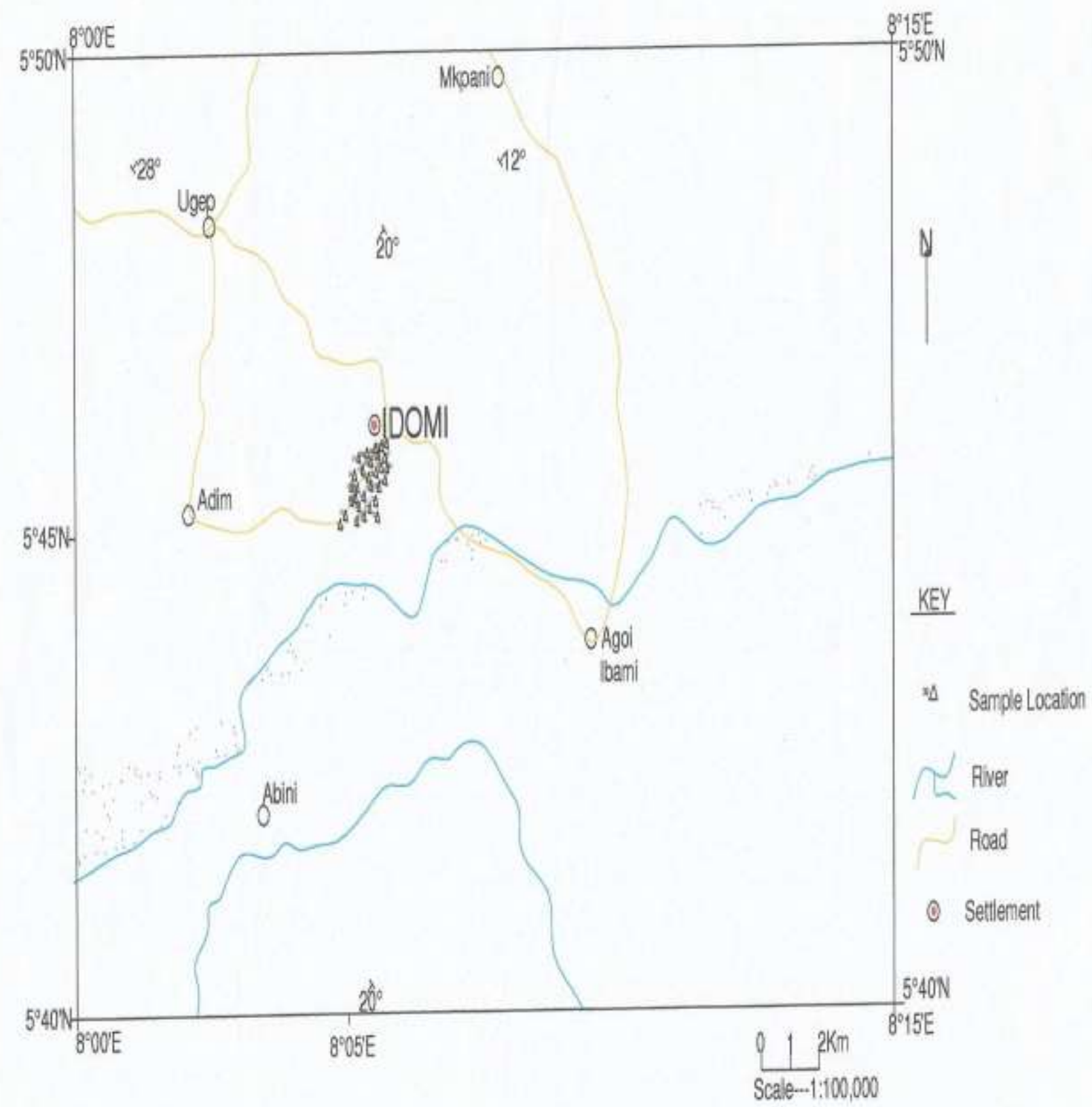

Fig 2: Map of Idomi and Environs showing sample collection positions

\section{Determination of Soil Radioactivity}

In order to determine soil radionuclide activity concentration, 30 stations which had different geological structure, were selected for this study (Fig.1). Soil samples were obtained from uncultivated locations that were close to settlements. Open, flat and undisturbed geographical locations which had good water permeability were selected as the sampling points (Fig. 2). Two hundred grams $(200 \mathrm{~g})$ of soil was taken at $10 \mathrm{~cm}$ below the topsoil. Foreign bodies were removed and the remaining soil was placed in clean, sealed and labelled bags. The samples were dried at $60{ }^{\circ} \mathrm{C}$ for $48 \mathrm{~h}$, grained, passed through $2 \mathrm{~mm}$ sieves and placed in Marinelli type beakers. The samples were kept one month before the analysis at airtight condition to allow secular equilibrium between thorium and radium and their decay products. The system was calibrated using standard mixtures of gamma spectroscopy and was counted for 50000s using a gamma spectrometer. The gamma spectrometry analysis was done at the Centre for Energy and Research Development, Ile- Ife, Nigeria. The detector of the 
gamma spectrometer used in this study was $7.6 \mathrm{~cm}$ x $7.6 \mathrm{~cm} \mathrm{Na1}$ (TI) Crystal located inside a lead castle. Its accessories include a Canberra multichannel analyzer (MCA) and photomultiplier tube.

The activities of the samples were determined using the total net counts under the selected photo peaks, the measured photo peak efficiency, gamma intensity and weight of the samples. After correcting for the background and Compton contribution, the activity concentrations of ${ }^{238} \mathrm{U},{ }^{232} \mathrm{Th},{ }^{226} \mathrm{Ra},{ }^{40} \mathrm{~K}$ and ${ }^{137} \mathrm{Cs}$ were determined. The ${ }^{238} \mathrm{U}$ and ${ }^{232} \mathrm{Th}$ were calculated assuming secular equilibrium was established with their decay products [238U series: ${ }^{226} \mathrm{Ra}(186.0 \mathrm{keV})$ and ${ }^{214} \mathrm{Bi}(609.2 \mathrm{keV}):{ }^{232} \mathrm{Th}$ series: ${ }^{228} \mathrm{Ac}(911 \mathrm{keV}),{ }^{208} \mathrm{TI}(583.1 \mathrm{keV})$.

\section{Radiological Hazard Index}

These represent methods to assess the collective effect of the activity mass concentration of ${ }^{40} \mathrm{~K},{ }^{226} \mathrm{Ra}$ and ${ }^{232} \mathrm{Th}$ present in a material in a single quantity.

\section{External Hazard Index-}

This is represented by the equation (Beretka and Mathew, 1985; Krieger, 1981).

$$
\begin{aligned}
& \mathrm{Hex}=\underline{\mathrm{Ra}}_{\mathrm{eq}}=\underline{\mathrm{A}}_{\mathrm{k}}+\underline{\mathrm{A}}_{\underline{R a}_{-}}+\underline{\mathrm{A}}_{\mathrm{Th}} \\
& \begin{array}{llll}
370 & 4810 & 370 & 259
\end{array}
\end{aligned}
$$

Where $A_{k}, A_{R a}$ and $A_{T h}$ represent the specific activities in $\mathrm{Bqkg}^{-1}$ respectively of ${ }^{40} \mathrm{~K},{ }^{226} \mathrm{Ra}$ and ${ }^{232} \mathrm{Th}$ in the equation. The symbol $\mathrm{Ra}_{\mathrm{eq}}$ stands for radium equivalent activity in $\mathrm{Bqkg}^{-1}$

To qualify for a safe material, therefore,

$$
\mathrm{H}_{\mathrm{ex}} \leq 1
$$

(Bereka and Mathew, 1985; Krieger, 1981; Krisiuk et al, 1971)

$$
\text { Or } \mathrm{Ra}_{\mathrm{eq}} \leq 370 \mathrm{Bqkg}^{-1}
$$

$\mathrm{Ra}_{\mathrm{eq}}=\mathrm{A}_{\mathrm{Ra}}+1.43_{\mathrm{Th}}+0.077_{\mathrm{Ak}}$

\section{Internal hazard index-}

This is described by (Beretka and Mathew, 1985; Krieger, 1981; Krisivk et al, 1971).

$$
\begin{aligned}
& \mathrm{H}_{\mathrm{in}}=\underline{\mathrm{A}}_{\underline{k}}+\underline{\mathrm{A}}_{\underline{R a}_{-}}+\underline{\mathrm{A}}_{\underline{T h}} \\
& \begin{array}{lll}
4810 & 185 & 259
\end{array}
\end{aligned}
$$

Also, $\mathrm{H}_{\text {in }} \leq 1$

\section{Gamma Index $(\mathbf{I} \gamma)-$}

This is another radiation hazard index by European Commission (EC). It is calculated by the following formula (EC, 1999, Cottons, 1990).

$$
\mathrm{I} \gamma=\frac{A K}{3000}+\frac{A R a}{300}+\frac{A T h}{200}
$$

I $\gamma$ is correlated with the annual dose rate due to gamma radiation.

I $\gamma \leq 1$ corresponds to an annual effective dose less than or equal $1 \mathrm{mSv}$ while $\mathrm{I} \gamma \leq 0.5$ corresponds to an annual effective dose less than or equal $0.3 \mathrm{mSv}$ (EC, 1999; Righi and Bruzzi, 2006). The EC has suggested that building materials that do not increase the annual effective dose of a member of public by $0.3 \mathrm{mSv}$ at the most should be exempted from all restrictions concerning a radioactivity hazard (EC, 1999). On the other hand, doses higher than $1 \mathrm{mSvy}^{-1}$ are allowed only on exceptional cases where materials are used locally.

\section{External dose rate-}

The external dose delivered by these radionuclide to the general public at a distance of $1 \mathrm{~m}$ above the surface was estimated from the measured specific activities of these nuclides by the following relationship (UNSCEAR, 2000). The average value of background dose rate from soil is $\left(5 \mathrm{I} \mathrm{nGyh}^{-1}\right)$ (UNSCEAR, 2000)

$$
\mathrm{D}^{*}=0.0417_{\mathrm{Ak}}+0.462_{\mathrm{ARa}}+0.604_{\mathrm{ATh} .}-
$$

Where $\mathrm{D}^{*}=$ Dose rate in $\mathrm{nGyh}^{-1}$ at $1 \mathrm{~m}$ above the ground surface. 
$\mathrm{Ak}, \mathrm{ARa}$ and $\mathrm{ATh}$ are the specific activities in $\mathrm{BqKg}^{-1}$ of ${ }^{40} \mathrm{~K},{ }^{226} \mathrm{Ra}$ and ${ }^{232} \mathrm{Th}$ respectively. The other radionuclide e.g. ${ }^{137} \mathrm{Cs},{ }^{90} \mathrm{Sr}$ and those present in the ${ }^{235} \mathrm{U}$ decay series, can be neglected as they contribute very little to the total dose from the environmental background. (Quindos et al, 1994; Deworm et al, 1998; Singh et al, 2005).

\section{Effective Dose Rate -}

The absorbed dose rate in air due to measured specific activities of the primary radionuclide in the sample was converted to effective dose rate by the following relationship. (UNSCEAR,2000; Akhtar and Tufail, 2007).

$$
\mathrm{E}=\mathrm{D}^{*} \times 0 \times \mathrm{C} \times 8760 \times 10^{-6}
$$

Where:

$$
\begin{array}{llll}
\mathrm{E} & = & \text { Effective dose rate }\left(\mathrm{mSVy}^{-1}\right) \\
* \mathrm{D} & = & \text { Absorbed dose rate in air }\left(\mathrm{nGyh}^{-1}\right) \text { at } 1 \mathrm{~m} \text { above the } \\
0 & = & 0.2(\text { Outdoor occupying factor) } \\
\mathrm{C} & = & 0.7 \mathrm{SvGy}^{-1} \text { (conversion factor from the absorbed dose in air to the effective dose received by an }
\end{array}
$$
adult person). The average background outdoor effective dose rate from soil for an adult person is $0.07 \mathrm{mSv}$. (UNSCEAR, 2000).

\begin{tabular}{|c|c|c|c|c|}
\hline $\mathrm{S} / \mathrm{n}$ & Sample names/location & $\mathrm{K}-40$ & $\mathrm{U}-238$ & Th-232 \\
\hline 1 & $\mathrm{~S} 1$ & $525.30 \pm 4.82$ & $50.03 \pm 4.06$ & $100.12 \pm 23.86$ \\
\hline 2 & S2 & $1033.30 \pm 7.05$ & $63.68 \pm 4.94$ & $130.46 \pm 28.93$ \\
\hline 3 & S3 & $1222.03 \pm 7.88$ & $108.89 \pm 7.42$ & $159.48 \pm 34.93$ \\
\hline 4 & $\mathrm{~S} 4$ & $599.22 \pm 5.06$ & $60.20 \pm 4.71$ & $171.66 \pm 36.74$ \\
\hline 5 & S5 & $570.13 \pm 4.81$ & $54.80 \pm 4.40$ & $82.15 \pm 20.02$ \\
\hline 6 & S6 & $440.37 \pm 4.25$ & $29.25 \pm 2.88$ & $28.33 \pm 9.42$ \\
\hline 7 & S7 & $539.04 \pm 102.30$ & $4.46 \pm 1.41$ & $13.37 \pm 2.33$ \\
\hline 8 & S8 & $893.33 \pm 6.56$ & $37.22 \pm 3.34$ & $67.51 \pm 17.79$ \\
\hline 9 & S9 & $743.92 \pm 5.65$ & $37.06 \pm 3.43$ & $83.08 \pm 20.67$ \\
\hline 10 & $\mathrm{~S} 10$ & $850.86 \pm 6.20$ & $28.50 \pm 2.90$ & $26.51 \pm 9.30$ \\
\hline 11 & $\mathrm{~S} 11$ & $762.00 \pm 5.77$ & $37.19 \pm 3.40$ & $86.08 \pm 20.43$ \\
\hline 12 & S12 & $1054.54 \pm 7.09$ & $33.65 \pm 3.18$ & $70.41 \pm 17.77$ \\
\hline 13 & $\mathrm{~S} 13$ & $975.90 \pm 6.90$ & $39.01 \pm 3.41$ & $99.73 \pm 23.29$ \\
\hline 14 & $\mathrm{~S} 14$ & $669.21 \pm 5.52$ & $43.16 \pm 3.68$ & $111.80 \pm 25.53$ \\
\hline 15 & S15 & $1215.74 \pm 7.89$ & $34.08 \pm 3.22$ & $60.25 \pm 15.88$ \\
\hline 16 & S16 & $1049.82 \pm 7.25$ & $46.11 \pm 3.90$ & $132.82 \pm 29.17$ \\
\hline 17 & S17 & $1494.12 \pm 9.15$ & $31.26 \pm 3.02$ & $114.89 \pm 26.07$ \\
\hline 18 & $\mathrm{~S} 18$ & $609.44 \pm 5.25$ & $49.11 \pm 4.19$ & $86.32 \pm 20.91$ \\
\hline 19 & S19 & $1178.00 \pm 7.74$ & $24.62 \pm 2.62$ & $93.34 \pm 21.91$ \\
\hline 20 & $\mathrm{~S} 20$ & $1026.23 \pm 7.22$ & $35.08 \pm 3.31$ & $132.43 \pm 29.44$ \\
\hline 21 & $\mathrm{~S} 21$ & $741.56 \pm 5.85$ & $61.10 \pm 4.69$ & $101.74 \pm 23.77$ \\
\hline 22 & $\mathrm{~S} 22$ & $968.82 \pm 6.79$ & $23.58 \pm 2.63$ & $67.71 \pm 17.26$ \\
\hline 23 & $\mathrm{~S} 23$ & $437.23 \pm 4.33$ & $37.06 \pm 3.38$ & $112.49 \pm 25.74$ \\
\hline 24 & $\mathrm{~S} 24$ & $982.19 \pm 6.74$ & $35.69 \pm 3.35$ & $100.51 \pm 23.36$ \\
\hline 25 & $\mathrm{~S} 25$ & $754.93 \pm 5.74$ & $46.13 \pm 3.79$ & $75.22 \pm 18.68$ \\
\hline
\end{tabular}

\section{RESULTS}

Table 1: Counts per second due to background radiation

\begin{tabular}{lll}
\hline & ${ }^{238} \mathrm{U}$ & ${ }^{232} \mathrm{Th}$ \\
$0.01572 \pm 0.0007$ & $0.03142 \pm 0.0008$ & \\
$0.08674 \pm 0.0001$
\end{tabular}

Table 2: Mean and standard deviation of the concentration of the radionuclide in soil samples $\left(\mathrm{Bqkg}^{-1}\right)$ 
Asian Journal of Applied Sciences (ISSN: 2321 - 0893)

Volume 07 - Issue 01, February 2019

\begin{tabular}{lllll}
26 & S26 & $1160.70 \pm 7.69$ & $46.13 \pm 3.79$ & $48.51 \pm 13.53$ \\
27 & S27 & $886.25 \pm 6.27$ & $37.91 \pm 3.38$ & $74.59 \pm 18.31$ \\
28 & S28 & $460.82 \pm 4.42$ & $33.53 \pm 3.15$ & $54.55 \pm 14.48$ \\
29 & S29 & $792.67 \pm 6.12$ & $40.32 \pm 3.54$ & $78.56 \pm 19.37$ \\
30 & S30 & $570.91 \pm 4.82$ & $25.29 \pm 2.62$ & $71.15 \pm 17.48$ \\
\hline & Mean & $506.13 \pm 9.30$ & $41.14 \pm 3.59$ & $84.52 \pm 20.88$ \\
& Maximum & $1494.12 \pm 9.15$ & $108.89 \pm 7.42$ & $171.66 \pm 36.74$ \\
& minimum & $437.23 \pm 4.33$ & $4.46 \pm 1.41$ & $13.37 \pm 2.33$ \\
\hline
\end{tabular}

TABLE 3: Radiation hazard indices of soil samples

\begin{tabular}{|c|c|c|c|}
\hline$S / n$ & Sample names/location & External hazard $\left(\mathrm{H}_{\mathrm{ex}}\right)$ & Internal hazard \\
\hline 1 & S1 & 0.64 & 0.77 \\
\hline 2 & S2 & 0.88 & 1.05 \\
\hline 3 & S3 & 1.16 & 1.46 \\
\hline 4 & S4 & 0.94 & 1.14 \\
\hline 5 & S5 & 0.59 & 0.74 \\
\hline 6 & S6 & 0.28 & 0.36 \\
\hline 7 & S7 & 0.17 & 0.18 \\
\hline 8 & S8 & 0.55 & 0.65 \\
\hline 9 & S9 & 0.57 & 0.67 \\
\hline 10 & S10 & 0.36 & 0.43 \\
\hline 11 & S11 & 0.59 & 0.69 \\
\hline 12 & S12 & 0.58 & 0.67 \\
\hline 13 & S13 & 0.70 & 0.80 \\
\hline 14 & S14 & 0.56 & 0.67 \\
\hline 15 & S15 & 0.57 & 0.66 \\
\hline 16 & S16 & 0.85 & 0.98 \\
\hline 17 & S17 & 0.83 & 0.92 \\
\hline 18 & S18 & 0.59 & 0.70 \\
\hline 19 & S19 & 0.67 & 0.73 \\
\hline 20 & S20 & 0.81 & 0.91 \\
\hline 21 & S21 & 0.71 & 0.87 \\
\hline 22 & S22 & 0.52 & 0.59 \\
\hline 23 & S23 & 0.62 & 0.72 \\
\hline 24 & S24 & 0.69 & 0.78 \\
\hline 25 & S25 & 0.57 & 0.70 \\
\hline 26 & S26 & 0.55 & 0.68 \\
\hline 27 & S27 & 0.57 & 0.67 \\
\hline 28 & S28 & 0.40 & 0.49 \\
\hline 29 & S29 & 0.57 & 0.68 \\
\hline \multirow[t]{4}{*}{30} & S30 & 0.46 & 0.55 \\
\hline & Average & 0.62 & 0.71 \\
\hline & Maximum & 1.16 & 1.46 \\
\hline & Minimum & 0.17 & 0.18 \\
\hline
\end{tabular}


TABLE 4: Gamma index of soil samples

\begin{tabular}{|c|c|c|}
\hline $\mathrm{S} / \mathrm{N}$ & Sample names/locations & Gamma Index $(\mathrm{I} \gamma)$ \\
\hline 1 & $\mathrm{~S} 1$ & 0.85 \\
\hline 2 & $\mathrm{~S} 2$ & 1.20 \\
\hline 3 & S3 & 1.57 \\
\hline 4 & $\mathrm{~S} 4$ & 1.26 \\
\hline 5 & S5 & 0.78 \\
\hline 6 & S6 & 0.39 \\
\hline 7 & S7 & 0.26 \\
\hline 8 & S8 & 0.76 \\
\hline 9 & S9 & 0.79 \\
\hline 10 & S10 & 0.51 \\
\hline 11 & S11 & 0.80 \\
\hline 12 & $\mathrm{~S} 12$ & 0.83 \\
\hline 13 & S13 & 0.96 \\
\hline 14 & S14 & 0.92 \\
\hline 15 & S15 & 0.82 \\
\hline 16 & S16 & 1.16 \\
\hline 17 & S17 & 1.17 \\
\hline 18 & S18 & 0.79 \\
\hline 19 & S19 & 0.94 \\
\hline 20 & S20 & 1.12 \\
\hline 21 & $\mathrm{~S} 21$ & 0.96 \\
\hline 22 & $\mathrm{~S} 22$ & 0.74 \\
\hline 23 & $\mathrm{~S} 23$ & 0.83 \\
\hline 24 & $\mathrm{~S} 24$ & 0.95 \\
\hline 25 & $\mathrm{~S} 25$ & 0.78 \\
\hline 26 & S26 & 0.78 \\
\hline 27 & S27 & 0.80 \\
\hline 28 & S28 & 0.53 \\
\hline 29 & S29 & 0.78 \\
\hline \multirow[t]{4}{*}{30} & $\mathrm{~S} 30$ & 0.63 \\
\hline & Mean & 0.86 \\
\hline & Maximum & 1.57 \\
\hline & Minimum & 0.26 \\
\hline
\end{tabular}

TABLE 5: Radium equivalent activity of soil samples

\begin{tabular}{ccc}
\hline S/N & Sample names/locations & Radium equivalent activity $\left(\mathrm{Bqkg}^{-1}\right)$ \\
\hline 1 & $\mathrm{~S} 1$ & 23365 \\
2 & $\mathrm{~S} 2$ & 329.8 \\
3 & $\mathrm{~S} 3$ & 431.05 \\
4 & $\mathrm{~S} 4$ & 351.81 \\
5 & $\mathrm{~S} 5$ & 216.17 \\
6 & $\mathrm{~S} 6$ & 103.67 \\
7 & $\mathrm{~S} 7$ & 65.09 \\
8 & $\mathrm{~S} 8$ & 202.55 \\
9 & $\mathrm{~S} 9$ & 213.14 \\
10 & $\mathrm{~S} 10$ & 131.93 \\
11 & $\mathrm{~S} 11$ & 218.95 \\
12 & $\mathrm{~S} 12$ & 215.54 \\
13 & $\mathrm{~S} 13$ & 256.76 \\
14 & $\mathrm{~S} 14$ & 254.56
\end{tabular}




\begin{tabular}{lcc}
15 & $\mathrm{~S} 15$ & 213.85 \\
16 & $\mathrm{~S} 16$ & 316.88 \\
17 & $\mathrm{~S} 17$ & 206.47 \\
18 & $\mathrm{~S} 18$ & 219.48 \\
19 & $\mathrm{~S} 19$ & 228.81 \\
20 & $\mathrm{~S} 20$ & 303.45 \\
21 & $\mathrm{~S} 21$ & 263.69 \\
22 & $\mathrm{~S} 22$ & 195.01 \\
23 & $\mathrm{~S} 23$ & 231.59 \\
24 & $\mathrm{~S} 24$ & 255.05 \\
25 & $\mathrm{~S} 25$ & 211.82 \\
26 & $\mathrm{~S} 26$ & 204.87 \\
27 & $\mathrm{~S} 27$ & 212.81 \\
28 & $\mathrm{~S} 28$ & 147.02 \\
29 & $\mathrm{~S} 29$ & 213.70 \\
30 & $\mathrm{~S} 30$ & 170.99 \\
\hline & Mean & 227.34 \\
& Maximum & 431.05 \\
\end{tabular}

\section{DISCUSSION}

From this study, it was seen that the radionuclide in the soil samples from Idomi were Potassium - 40, Uranium - 238 and Thorium - 232 .

The mean activity concentrations and their standard deviations of radionuclide in soil samples from Idomi were $506.13 \pm 9.30,41.14 \pm 3.59$ and $84.52 \pm 20.88 \mathrm{Bqkg}^{-1}$ respectively for ${ }^{40} \mathrm{~K},{ }^{238} \mathrm{U}$ and ${ }^{232} \mathrm{Th}$ (Table 2). The worldwide median values are 35, 30 and $400 \mathrm{BqKg}^{-1}$ for ${ }^{238} \mathrm{U},{ }^{232} \mathrm{Th}$ and ${ }^{40} \mathrm{~K}$ respectively (UNSCEAR, 2000). Hence, the mean activities of these radionuclide in the sampling locations are comparable with world median ranges. The variation in their activities may be attributed to the types, moisture content, inhomogenity of its permeability (Varley and Flowers, 1998), formation, transport processes and geomorphology (El-Arabi, 2005) associated with meteorological conditions.

Their external (Hex) and internal (Hin) hazard indices was 0.62 and 0.71 respectively (Table 3). The calculated gamma index was 0.86 and had a range 1.57- 0.26 (Table 4). These radiation hazard indexes are less than 1 and are indicative that soils from Idomi can be used for construction purposes (EC 1999).

The mean radium equivalent activity of soil samples from Idomi is $227.34 \mathrm{Bqkg}^{-1}$ (Table 5). This is less than 370 $\mathrm{Bqkg}^{-1}$ which is the world average (Tsai et al, 2008). The calculated absorbed gamma dose from the soil samples $1 \mathrm{~m}$ above the ground level was $110.31 \mathrm{nGyh}^{-1}$ and ranges between 32.62 to $198.08 \mathrm{nGyh}^{-1}$. This range falls within the typical range for measured absorbed dose rate in outdoor air which is $10-200 \mathrm{nGyh}^{-1}$ (UNSCEAR, 2000).

The calculated mean annual outdoor effective dose of soil samples from Idomi was $1.35 \mathrm{mSvy}^{-1}$. This is lower than the global average of $2.4 \mathrm{mSvy}^{-1}$ (UNSCEAR, 2000).

\section{CONCLUSION}

The radiation hazard indices, absorbed and effective doses from soil samples can be said to be low when compare with their corresponding global average. The probability of occurrence of health effects from exposure to natural terrestrial gamma radiation in Idomi can be said to be low. This may be possible if the baseline level(s) can be kept constant by keeping the environment free of radioactive pollution or waste. 


\section{REFERENCES}

- Akhtar, N. and Tufail, M. (2007). Natural radioactivity intake in wheat grown on fertilized farms in two districts of Pakistan. Radiat. Prot. Dosim. 123: 103-12.

- Beretka, J. and Mathew, P.T. (1985). Natural radioactivity of Australian building materials, industrial wastes and by-products. Health Physics 48: 87-95.

- Cottons, E. (1990). Actions against radon at the international level. Proc. Symp. ON SRBII (Journey Radon)(Brussels: Royal Society of Engineers and Industrial of Belgium) 95.

- Deworm, J.T., Slegers, W.; Gillard, J.; Flemal, J.M. and Culst, J.P. (1998). Survey of the natural radiation of Belgium territory as determined by different methods. Radiat Prot. Dosim 24: 347-351.

- Ekwueme, B. N. (1990). On the occurrence of crystalline (basement complex) rock in Ugep, Nigeria. J. Min. Geol., 26 1:69-74.

- Ekwueme, B.N. (1995). Geochemistry of crystalline basement rocks in SW Ugep, Nigeria. Dec-Ford Journal of Pure and Applied Sciences 11:15-28.

- El-Arabi, A.M. (2005). Natural radioactivity in sand used in thermal therapy at the Red Sea Coast. J. Environs Radioact 81: 11-19.

- European Commission (1999). Radiological protection principles concerning the natural radioactivity of building materials. Radiation Protection 112 (Brussels: European Commission) 100-101.

- Hendry J. H. Simmon S. L. Wojcik A., Sohrabim M, Burkart W, Cardis E, Laurier D, Timarche M. and Hayata I. (2009). Human exposure to high natural background radiation: what can it teach us about radiation risk? J. Radiol.Proct.29:A29-A42

- Krieger, R. (1981). Radioactivity of construction materials. Bentonwerk Fertigtiel Tech. 47: 468.

- Krisiuk, E. M., Tarasov, S. T. and Shamov, V.P. (1971). A study on radioactivity of building materials (Leningrad: Research Institute of Hygiene) 106.

- $\quad$ NRPB (1994). Radiation Dose-Maps and Magnitudes. At a Glance series.

- Quindos, L.S.; Fernandez, P.L.; Soto, J. ; Rodenas, C. and Gomez, J. (1994). Natural radiactivity in Spanish Soils. Health phys (66): 194-200.

- Righi,S. and Bruzzi, L. (2006). Natural radioactivity and radon exhalation in building materials used in Italian dwellings. J. Environ. Radioact, 88: 158-70.

- Singh, S.; Raci, A. and Mahajan, R. K. (2005). 226-Ra, 232-Th and 40-K analysis in soil samples from some areas of Punjab and Himachal Pradesh, India using gamma ray spectrometry. Radiat. Meas. 39:431-439.

- Tsai T, Chun-chih L, Tzu-Wen W and Tieh-chii C. (2008). Radioactivity concentrations and dose assessment for soil samples around nuclear power plant IV in Taiwan J. Radio Prot. 28: 347-360.

- UNSCEAR (2000). Sources, Effects and risks of ionization radiation. Report to the general assembly, with scientific Annexes B. Exposures from Natural Radiation sources (New York: UNSCEAR) 67.

- Uwah E. J. 1993). The use of Aeroradiometric data for environmental monitoring: A case study of Ugep area of Cross River State, Nigeria. Nigeria J. Phys. Vol. 5, p. 48-57.

- Varley, N. R. and Flowers, A.G. (1998). Indoor radon prediction from soil gas measurement. Health phys. 74:7148. 